\title{
Strategy Of Illegal Technology Financial Management In Form Of Online Loans
}

\author{
Raden Ani Eko Wahyuni* \\ Faculty of Law, Diponegoro University \\ *radenani45@gmail.com
}

\begin{tabular}{|l|}
\hline \multicolumn{1}{|c|}{ Published: 30/03/2020 } \\
\hline How to cite (in APA style): \\
$\begin{array}{l}\text { Wahyuni, R, A, E. (2020). Strategy Of Illegal Technology Financial Management In Form Of Online Loans. Jurnal Hukum } \\
\text { Prasada, 7(1), 27-33. doi: https://doi.org/10.22225/jhp.7.1.1324.27-33 }\end{array}$ \\
\hline
\end{tabular}

\begin{abstract}
The existence of technological development has an impact on aspects of people's economic life. The emergence of financial technology in the form of online loans makes it easy to get the desired funds in a short and easy process. This study aims to discuss the practice of illegal online lending from the perspective of business ethics. The research method used is Normative Juridical with descriptive analytical research specifications. In the practice of Financial Technology (fintech), namely online loans, several problems have been discovered, such as the emergence of illegal online loans, recorded from January 2018 to April 2019, the Financial Services Authority has blocked 947 types of fintech entities in the form of loans between unlicensed online parties. The existence of illegal financial technology can lead to criminal acts such as fraud, money laundering or misuse of consumer's data. This condition was triggered by many people who did not yet know about the technology financial business. Even for legal online loan services that already have risks, the illegal ones will certainly be more risky, and the last many reports from the public as victims of unethical debt collection by online loan service companies. This happens because of the lack of public knowledge about the legality of online loan service companies.
\end{abstract}

Keywords: Finacial Technology, Online Loans, Strategy

\section{Introduction}

Along with technological advancements in the national economy is improved to achieve people's welfare in order to realize a better economic life (Wahyuni, 2019). Along with the development of the current era of globalization, all kinds of community activities are inseparable from technological assistance. Similarly, the financial sector is now beginning to be integrated with the electronic system platform. The financial system is basically the order in a country's economy that has a role, especially in providing financial services facilities by financial institutions and other supporting institutions (Gazali \& Usman, 2016).

Along with the development in this era of globalization, any community activities will not be separated from technological assistance. Similarly, financial institutions are now beginning to shift to technology-based financial institutions. One of the advances in the financial sector today is the adaptation of Fintech (Financial Technology). Fintech itself comes from the term Financial Technology. According to The National Digital Research Center (NDRC), Fintech is an innovation in the financial sector. Of course, this financial innovation gets a touch of modern technology. The existence of Fintech can bring a more practical and secure financial transaction process (Crismantianto, 2017).

Fintech is the implementation and utilization of technology to improve banking and financial services that are generally carried out by startups by utilizing the latest software, internet, communication and computing technologies (Iman, 2016). This concept is 
adapting technological developments combined with the financial sector so that it can present a more practical, secure and modern financial transaction process. The basic forms of fintech include Payments (digital wallets, P2P payments), Investments (equity crowdfunding, Peer to Peer Lending), Financing (crowdfunding, micro-loans, credit facilities), Insurance (risk management), Cross-processing (big data analysis, predicitive modeling), Infrastructure (security).

This service provides a method of lending to borrowers (both individuals and business entities) and vice versa, borrowers can apply for loans to lenders. Online loan services connect lenders with online borrowers. Throughout 2018, lending by online loan service companies reached Rp22 trillion. The Financial Services Authority (OJK) notes that the figure comes from 99 online loan companies registered with OJK, and has performed services for more than 9 million transactions in more than 3 million people throughout Indonesia. This figure has increased almost eightfold when compared to lending through online loan services in 2017 which recorded Rp2.56 trillion. Of the Rp22 trillion in loans disbursed, the non-performing loan (NPL) ratio in 2018 was $1.45 \%$, an increase if compared to 2017 which was at the level of 0.99\% (Budiyanti, 2019).

The increasing value of online loan funding in the last three years shows that there is a high level of trust from the public towards companies providing online loan services. The majority of borrowers who are served online loans come from groups of workers, farmers, fishermen, craftsmen, and Micro, Small and Medium Enterprises (MSMEs) (Dunia Fintech, 2017). The reason borrowers make loans online is the difficulty in accessing formal financial services with various administrative requirements that must be met. Online loan administration requirements are relatively easier when compared to formal financial service loans.

The rapid growth of illegal online loan services is also due to the potential of the Indonesian people themselves who are becoming a sizable market for online loan services. There are still many Indonesians who are not bankable, so many are turning to illegal online loan services, which are easier and faster. In addition, with the existing online loan service regulation, it still provides an opportunity for companies to choose not to register with OJK. Some of the reasons companies do not register with the OJK are as follows: (a) the company does not meet the existing requirements and (b) the company does not want to follow the OJK regulations which are considered difficult to fulfill or too strict.

From January 2018 to April 2019, the OJK Investment Alert Task Force has blocked 947 unlicensed peer to peer lending entities. The company is said to be illegal because it is not in accordance with OJK Regulation Number 77 / POJK.01 / 2016 regarding Information Technology-Based Public Lending and Borrowing Services. The regulation regulates, fintech companies are required to submit permission to the OJK to conduct their business. The requirements that must be met are the deed of establishment of legal entity, register of ownership, shareholder data, and data of directors and commissioners (Kompas Daily, 2019). Even though efforts have been made to block even a few thousand illegal fintechs, many illegal fintech applications still exist. Illegal Fintech types of loans between parties through online are aggressively offering loans through short messages, internet advertisements, and offer with the lure of easy loan terms by including the application link address. Thus, it is very interesting to study deeper into the need for strategies to tackle financial Illegal technology in the form of online loans. Therefore, this study aims to discuss the practice of illegal online lending from the perspective of business ethics.

\section{METHOD}

This research activity is an activity carried out in an effort to understand and solve problems scientifically, systematically and logically (making sense). A study was initiated because of the gap between das sollen and das sein, that is, between existing theories and realities that occur in the field, the method of approach used in this study is a normative juridical approach, given the problems studied and studied besides holding on to juridical aspects, which are based on norms, regulations, legal theories. In other words, this research not only refers to the applicable legal 
products but also based on the reality that is happening in the field. The specifications used in this study are analytical descriptive because this study is expected to obtain a clear, detailed and systematic picture, while it is said analytical because the data obtained will be analyzed for solving problems in accordance with applicable legal provisions, the purpose of the study uses descriptive analytical specifications to provide a picture of reality in objectively examined objects (Zainuddin, 2019).

\section{RESULT AND DISCUSSION}

Financial technology is part of the application of information technology in the financial sector. Although there is no standard definition, basically fintech is a segment of the start-up world that has a focus on maximizing the use of technology to change, accelerate or sharpen various aspects of financial services available today. Implementation of Financial Technology is categorized into: payment systems; market supporters; investment management and risk management; loans, financing and capital supply; and other financial services (Yuking, 2018). Online loan business or (P2P Lending) is one form of development in the business world. The development of a rapidly growing business is a challenge for businesses to maintain the continuity of their business activities (Fauzan, \& Nuryana, 2014).

The use of peer to peer lending online or financial technology (fintech) loan services is becoming more massive nowadays. Ease in borrowing funds is one of the advantages of financial services compared to banks. In a matter of days, loans can be immediately disbursed without the hassle of visiting a bank. Now people can easily get funds just by providing their personal data. The ease with which financial technology provides the risk of violation which will be even higher if the data held by the service provider is managed by a system that is not qualified and transparent (with an assessment that refers to the criteria / standardization of eligibility and transparency provided by a special commission) (Dewi, 2016).

Unfortunately, the development of the fintech industry is also closely related to the negative stigma of society, especially in billing. The public often complains about the mechanism of billing fintech companies intimidatively to the point of containing sexual harassment. One of the threats made by fintech companies in billing is in the form of reports to the police to be subject to criminal sanctions. Facing this threat, ordinary people of the law certainly feel worried about facing the lawsuit. So, is it possible for a borrower to be legally liable to criminal sanctions if it fails to return the loan to a fintech company? If, "law enforcement officers continue to provide criminal sanctions to debtors, then this action is a violation of the Act. Human Rights Law ". Article 19: (2) No person in a court decision may be sentenced to prison or confinement based on the inability to fulfill an obligation in the debt and credit agreement. Borrowing Money Based on Information Technology has not been able to resolve this dispute. Because, the contents of these rules do not have dispute resolution institutions in the fintech industry so that each dispute resolution is associated with the criminal realm.

Forms of infringement of fintech companies especially illegal ones are also of various types. From intimidating billing, distribution of personal data to sexual harassment allegedly occurred in this matter. One of the types of alleged violations came from the results of public complaints reports received by the Jakarta Legal Aid Institute $(\mathrm{LBH})$ since last year. Jakarta Legal Aid recorded 14 violations of law and human rights experienced by victims of online loan applications. The violations are as follows (Rizky, 2019):

The existence of this illegal online loan service company certainly has a negative impact, among these impacts, namely:

Illegal online loan services can be used as a means to commit money laundering or terrorism financing.

Misuse of data and information on service users or consumers in this case the public. People are not aware that online loan service companies also record various personal data 
contained in their smartphones when registering.

Lost potential tax revenue. Of course, the potential tax from illegal online loan services is huge considering the amount is more than that registered with the FSA.

There are still many people who do not know about online loan services, so that when conducting credit transactions, the community as a borrower often does not see in detail the contents of the provisions or loan agreements. This causes the community to be ensnared with very high interest. Commission or interest from illegal online loans reaches an average of more than $40 \%$ of the principal debt plus a fine of $\operatorname{Rp} 50,000$ per day.

NPL for online loans in 2018 will reach $1.45 \%$. This means that even legal online loan services have risks, even illegal ones will be more risky.

There are many reports from the public as victims of unethical debt collection by online loan service companies. This happens because of the lack of public knowledge about the legality of online loan service companies.

The rapid growth of illegal online loan services is also due to the potential of the Indonesian people themselves who are becoming a sizable market for online loan services. There are still many Indonesians who are not bankable, so many are turning to illegal online loan services, which are easier and faster. In addition, with the existing online loan service regulation, it still provides an opportunity for companies to choose not to register with OJK. Some reasons companies do not register with OJK are because companies do not meet existing requirements and companies do not want to follow OJK regulations which are considered difficult to fulfill or too strict (Budiyanti, 2019).

The targets of illegal fintech are people who lack financial knowledge, are urgently in need of money, and have a consumptive lifestyle. Various modes are used to ensnare prospective customers so that those without careful calculations are trapped and bear the risk (Kompas Daily, 2019). Forms of legal or illegal fintech violations should be the responsibility of the Financial Services Authority (OJK). "That (violation) is the responsibility of OJK that OJK Law articles 4,5 and 6 regulate it. So if you say what legal aspects ensnare online loans, it is clear that OJK itself has rules there, whether he is registered or not.

E-Money or electronic money, as the name suggests, is money that is packaged into the digital world, so that it can be said to be an electronic wallet. This money can generally be used to shop, pay bills, etc. through an application. One of those electronic wallets is Doku. Doku is an application that can be easily uploaded on smartphones. Doku is equipped with a credit card link feature and electronic money or cash wallet, which can be used to shop both online and offline anytime and anywhere through the application.

Start-up companies (startups) that have sprung up in Indonesia have their own characteristics in running the type of business that is run based on Financial Technology. The following classification of types of FinancialTechnology (World Fintech, 2017):

Along with the huge potential of online loan services, many online loan service companies have sprung up in Indonesia. Many investors are investing in the online loan service sector with a very high growth rate today. To overcome this, OJK as an independent financial services supervisory agency in Indonesia issued OJK Regulation (POJK) No. 77 / POJK.01 / 2016 concerning Information Technology-Based Money Lending and Borrowing Services, which requires online loan service companies to register their companies with OJK.

The emergence of financial companies in the field of information technology based lending and borrowing services (peer-to-peer or P2P lending) is increasingly gaining public and regulatory attention, namely the Financial Services Authority (OJK) and Bank Indonesia. This is stated in the Financial Services Authority Regulation No. 77 / POJK.01 / 2016 concerning Information Technology Based Lending and Borrowing Services. The POJK regulates information technology-based lending and borrowing services or it can be called peer-to-peer lending and borrowing. The rapid development of illegal online lending business (P2P Lending) is inevitable because one of them is the potential of the Indonesian people themselves, which is a big market opportunity for online lending business (P2P 
Lending), but due to the notion that borrowing money is felt to be done in banks have been assessed for too long so that many have switched to online lending business (P2P Lending), which is easier and faster. In addition, the existing online loan regulation (P2P Lending).

If we look at the law of civil lending and borrowing, it is an agreement with which one party gives the other party a certain amount of goods that are used up for use, provided that the latter party will return the same amount of the same type and quality. In the Implementation of Fintech, an agreement is made with electronic documents that connect the lender with the Loan Recipient who then forms a legal relationship. The basis is a binding agreement for the parties. Requirements for the validity of the agreement must also be fulfilled in accordance with Article 1320 of the Civil Rights: They agree to bind themselves, the ability to make an agreement, a certain matter, and a legal cause.

If the four conditions are fulfilled by the parties, then the agreement becomes valid which then has legal consequences as regulated in Article 1338 of the Civil Code, namely the agreement that has been valid as a law for the parties, cannot be canceled unilaterally and must be implemented in good faith / honest. If Article 1338 of the Civil Code has been fulfilled, then the agreement reaches the goal, thus the agreement between the two parties will be deleted. In a regulation, it is still possible that there are things that have not been able to protect the parties. For example, the Investree company if there is a loss in a defaulted transaction from the Loan Recipient, the Operator is not responsible for losses incurred by the Lender because the Operator is not a party in the agreement. Obviously there is no legal protection especially for Lenders in existing regulations.

Whereas if we look at the electronic agreements made in P2PL based on Fintech, they have binding legal force for the parties as is the agreement in general. This is regulated in Article 18 Paragraph 1 of Law Number 11 Year 2008 Regarding Information and Electronic Transactions which states that "electronic transactions as outlined in the electronic contract bind the parties". Then the electronic agreement applies as a law for the parties that bind themselves to each other, and result in the emergence of a legal relationship for the parties. Electronic agreements have something in common as safe agreements in general.

Thus it is necessary to have a strategy to tackle illegal online loans, among others (Budiyanti, 2019):

All of the above efforts, the role of OJK and the government is very important in overcoming illegal online loan services. However, related to the need for rules specifically dealing with illegal online loan services, the FSA and the government need the support of the House of Representatives of the Republic of Indonesia (DPR RI). In this case, the House of Representatives, especially the Commission XI, can carry out legislative and supervisory functions to oversee the existence of special regulations to deal with illegal online loan services.

Furthermore, there are other rules for fintech companies that are proven to have violated the law. For example, he explained that fintech companies that commit violations in the form of disclosure of personal data may be subject to Article 32 juncto (jo) Article 48 of Law No. 11 of 2008 Juncto Law No. 19 of 2016 concerning Information and Electronic Transactions (ITE). Then, the threat of fintech companies to customers can be charged with Article 368 of the Criminal Code (KUHP) and Article 29 in conjunction with Article 45B of the ITE Law, Dissemination of personal data (Article 32 in conjunction with Article 48 of the ITE Law), threats in billing (Article 368 of the Criminal Code) and Article 29 jo 45 of the ITE Law), Fraud (Article 378 of the Criminal Code), Defamation (311 Paragraph 1 of the Criminal Code), Sexual harassment through electronic media (Article 27 Paragraph 1 jo 45 Paragraph 1 of the ITE Law). Meanwhile, the Director of the "naughty" fintech company can also be charged under Article 55 of the Criminal Code for being involved in criminal acts. If, the criminal act takes the form of physical violence, the taking of goods may be subject to sanctions in accordance with KUHP Article 170, Article 351, Article 368 Paragraph 1, Article 335 Paragraph 1 after the decision of the Constitutional Court. Thus, consistency is needed in order to tackle illegal online loan services. 
The rapid growth of online lending business practices (P2P Lending) among the people is also caused by the potential of the Indonesian people themselves, which is a sizeable market for online lending business practices (P2P Lending). A company in running its business must of course consider the impact of what happens in its business activities. Seeing the problems that occur in the community related to illegal online lending business practices (P2P Lending) naturally raises a concern where business activities should prioritize honesty and do good to others.

\section{CONCLUSION}

The emergence of financial companies in the field of information technology based lending and borrowing services (peer-to-peer or P2P lending) is increasingly gaining public and regulatory attention, namely the Financial Services Authority (OJK) and Bank Indonesia. This is stated in the Financial Services Authority Regulation No. 77 / POJK.01 /2016 concerning Information Technology Based Lending and Borrowing Services. The POJK regulates information technology-based lending and borrowing services or it can be called peer-to-peer lending and borrowing. The existence of an illegal online loan service company certainly has a negative impact. The impact of including illegal online loan services can be used as a means to commit money laundering or terrorism financing, misuse of data and information on service users or consumers in this case the community, losing the potential for tax revenue, there are still many people who do not know about loan services online, online NPL loans in 2018 reached $1.45 \%$. This means, even for legal online loan services that already have risks, the illegal ones will certainly be more risky, and the last many reports from the public as victims of unethical debt collection by online loan service companies. This happens because of the lack of public knowledge about the legality of online loan service companies.

In order to overcome illegal online loans, steps needed include: the need for synergy of cooperation between the Ministry of Communication and Information Technology (OJK), OJK, and the police in overseeing online loan services to implement measures to prevent illegal online loan services, increase digital literacy in the community. Considering that the negative impact of illegal online loan services is greatest in the community, there is a need for literacy to the public regarding digital / technology-based loans, the need for regulations relating to protection for online ilegal loan service consumers. Based on PJOK No. 77 / POJK.01 / 2016 concerning Information Technology-Based Lending and Borrowing and Money Lending Services No.13 / POJK.02 / 2018 concerning Digital Financial Innovation in the Financial Services Sector, as well as the need for evaluation of licensing mechanisms or registration of online loan service companies at OJK. Similar to the rules regarding sanctions, based on PJOK No. 77 / POJK.01 / 2016 concerning Information TechnologyBased Lending and Borrowing Services and POJK No. 13 / POJK.02 / 2018 concerning Digital Financial Innovations in the Financial Services Sector.

\section{REFERENCES}

Budiyanti, E. (2019). Upaya Mengatasi Bisnis finansial teknologi llegal. Jurnal Info Singkat, Vol XI. No.04/II/Puslit, 20.

Chrismantianto, Imanuel Aditya, W. (2017). Analisis Swot Implementasi Teknologi Finansial Terhadap Kualitas Layanan Perbankan di Indonesia. Jurnal Ekonomi dan Bisnis: Fakultas IImu Pendidikan Universitas Pelita Harapan Tangerang, Vol. 20, (No.1, April 2017), 137.

Dunia Fintech. (2017) Apa itu Fintechdan Jenis Starup di Indonesia?. https://www.duniafintech.com/ pengertian-dan-jenis-startup-fintech-di-indonesia/, accesed kses pada Minggu, 23th June 2019.

Fauzan., \& Nuryana, Ida. (2014). Pengaruh Penerapan Etika Bisnis Terhadap Kepuasan Pelanggan Warung Bebek H. Slamet di Kota Malang. Jurnal MODERNISASI, Vol.10, (No.1), 38.

Gazali, Djoni S \& Usman,Rachmadi. (2016). Hukum Perbankan, Jakarta: Sinar Grafika.

Rizky, M. (2019). Permasalahan fintech ini bahkan merenggut nyawa nasabah yang memilih bunuh diri akibat depresi karena penagihan pinjaman. Berbagai bentuk pelanggaran fintechini dapat dijerat secara pidana. (online), (https://m.hukumonline.com/berita/baca/lt5c6cacf0c858c/pasalpasal-pidana-yang-bisa-jerat-perusahaan-fintech-ilegal/2019. 
Wahyuni, Raden Ani E. (2019). Implementation Of Legal Protection By The Government In Order To Empowerment Of Micro Small Medium Enterprise To Realize The Justice Economy (Research Study: The Office of Cooperative and Micro Small and Medium Enterprise Province of Central Java). Diponegoro law review. Vol. 04. No.01, 389.

Widi, H. (2019, Juni 17). Jerat Massal Fintech llegal, Harian Kompas.

Yuking, A. (2018). Urgensi Peraturan Perlindungan Data Pribadi Dalam Era Bisnis Fintech. Jurnal Hukum \& Pasar Modal, Vol. VIII. Ed. 16/2018, 2.

Zainuddin, M. (2019). Pemahaman Metode Penelitian Hukum (Pengertian, Paradigma, dan Susunan Pembentukan). Yogyakarta: CV.Istana Agency. 